Artigo original

Hegemonia - Revista Eletrônica do Programa de Mestrado em Direitos Humanos, Cidadania e Violência/Ciência Política do Centro Universitário Unieuro

ISSN: 1809-1261

UNIEURO, Brasília, número 23, Janeiro a Junho de 2018, pp. 5-26.

Recebido em: 29/8/2017

Avaliado em: 19/9/2017

Aprovado em: 30/10/2017

\title{
RETHINKING PARTIES, DEMOCRACY AND ELECTORAL REFORM: Obstacles and challenges
}

Rodolfo Marcilio Teixeira ${ }^{1}$ e Virgínia Motta Sousa ${ }^{2}$

Abstract: This paper attempts to elucidate the various concepts of democracy, political party and participation, observing its major obstacles faced in actuality, demonstrating the nature and complexity of the theoretical discussion. Focused on seminal and contemporary studies that scrutinize the sustenance of democracy and political institutions, it points out how the long distance between ideals and the obstacles of praxis hinders the process of consolidating these institutions. In conclusion, it emphasises that the task of consolidating democratic model requires a set institutional adjustments, amendments, reforms and the incorporation of information technology advancements that must be studied, prepared and slowly applied in order to achieve proper democratic consolidation.

Keywords: Democracy; Electoral reform; Political participation, Parties; Representation.

\section{INTRODUCTION}

The task of reforming the political system, whether by consolidating representativeness or strengthening governance, needs a solidly structured framework. However, the task of establishing this structure presents complex problems whose practical results have left much to be desired, as shown by opinion surveys around the world. The average satisfaction with democracy in 25 EU countries in 2006 was 54\% and 37\% in Latin America (MANGAHAS, 2007). After the

\footnotetext{
${ }^{1}$ Doutor em Sociologia e docente do Centro Universitário Unieuro.

${ }^{2}$ Mestre em Direitos Humanos, Cidadania e Violência/Ciência Política.
} 
Artigo original

Hegemonia - Revista Eletrônica do Programa de Mestrado em Direitos Humanos, Cidadania e Violência/Ciência Política do Centro Universitário Unieuro

ISSN: 1809-1261

UNIEURO, Brasília, número 23, Janeiro a Junho de 2018, pp. 5-26.

2008 economic crisis, there was a dramatic plunge in southern Europe (BELCHIOR, 2015), but the fragile democracies of Latin-American, such as Brazil, suffered the most.

Levels of satisfaction with political parties are even lower. The general opinion about these institutions is, in most cases, negative (Dalton \& Weldon, 2005). The growing mistrust in parties or in their capacity to solve contemporary economic and political problems contributes to reducing participation in elections; to fragment party systems; and to strengthen extremist protest parties in either side of the political spectrum, a set of factors that help to deteriorate opinion in relation to governments, as can be seen recently in Brexit and the rise of nationalist support for anti-system parties in France and Germany.

These difficulties occur because, in times of globalization and interdependent markets, parties and incumbents do not have the capability or resources to solve economic and political problems fast and efficiently enough. On the contrary, market veto players and internal political systems function in order to prevent this from happening. Elitist electoral systems contribute to defining, to a greater or lesser degree, party systems that vary in size and their internal structure. In any case, they generally do not represent the values and ideals of the society to which they belong. On the contrary, they reinforce structurally fragile, socially detached, internally fragmented, and undisciplined parties. This set of choices determines the poor kind of relationship established between society and the state, with parties as ineffective intermediaries.

On another level, educational public policy in almost every democratic society has been changed in order to sponsor a different set of skills that emphasize areas that furthers national profit and eliminates critical thinking. As a result, systems of education have carelessly discarded skills and knowledges that belong to the Humanities and keep democracies active, thus producing what has been called "useful machines" (NUSSBAUM, 2010). This affects not only the quality of democracy, but also overall support for the democratic approach.

This article attempts to point out some of the main problems involved in the modern discussion of democracy and political parties. Despite all problematic conceptualization, it is worth remembering that parties and electoral systems are conditioned by the historical and cultural experiences of their citizens, including what we learn and perceive in our individual experiences. Therefore, these institutions evolve in accordance with the new forms of social interaction provided by innovative technologies and are influenced by the structural changes in the economy and culture. This fluidity of variables represent both the possibility of creative and inclusive democratic projects and the establishment of oligarchic experiences. In this vein, conceptual differences in the way we view and shape electoral and party systems can bring diverse practical 
Artigo original

Hegemonia - Revista Eletrônica do Programa de Mestrado em Direitos Humanos, Cidadania e Violência/Ciência Política do Centro Universitário Unieuro

ISSN: 1809-1261

UNIEURO, Brasília, número 23, Janeiro a Junho de 2018, pp. 5-26.

results were the distance between beneficiaries and underprivileged can be immense. Unfortunately, the world is experiencing a time where democratic approach is being extensively challenged and weakened. In this sense, one should not expect stress-free solutions in terms of democratic representation and participation because, firstly, every change works in terms of losses and gains. Secondly, the current political and economic systems resist change.

\section{WHAT KIND OF DEMOCRACIE (IF SO) DO WE WHANT?}

The evolution of political theory has shown that the discussion involving conceptualization of democracy is complex and offers many operational possibilities. One may choose the representative perspective where the decision-making process is based on a set of procedures that resolve the battle between individual interests in a political market. On the other hand, there is the perspective where political participation is not only an instrument of decisionmaking, but an objective that assists in the formation of citizenship. Between these standpoints, there is an immense hall of possibilities.

By the end of the nineteenth century, the representative perspective originated from the prospect of maximizing freedom and guaranteeing control of the State through a representative government strengthened itself. The challenges of complex state structures in industrialized post French Revolution societies were increasingly distancing themselves from the Athenian experience and required a renewed model of democracy whose fundamental basis was no longer direct participation, but the establishment of elections and the use of political parties as the main intermediaries of the desires and anxieties of their represented.

The classical Platonic/Aristotelian doctrines were very far from the reality of nineteenth century Europe. It was thus fundamental to arrange a new conception of representation, capable of dealing with one of the problems of the classical understanding of democracy: the existence of rational and definitive individual opinions on any and all questions; that notion that elected representatives are capable of ensuring that voters' opinions are precisely and gracefully carried out. In other words, in a representative democracy, the rational argument would be able to lead any individual, as well as their elected representatives, to see together valid responses to obstacles to wellbeing and happiness, despite individual preferences, as long as certain criteria in terms of mechanics were met. Praxis proved this wrong.

In order to deal with these problems, Schumpeter (1961) defines the democratic method as follows: an institutional arrangement that reaches political decisions in which specific individuals 
Artigo original

Hegemonia - Revista Eletrônica do Programa de Mestrado em Direitos Humanos, Cidadania e Violência/Ciência Política do Centro Universitário Unieuro

ISSN: 1809-1261

UNIEURO, Brasília, número 23, Janeiro a Junho de 2018, pp. 5-26.

acquire the power to deliberate, based on the competitive contest by votes. According to him, this model substantially improves the theory of the democratic process, since it does not fall into the conceptual traps (common will, common good and human nature) employed by Rousseau (1986) and thinkers from the Utilitarian School, for example. Moreover, this model dispenses other harmful influences of a religious nature, for example, that Thomas Hobbes and (Again) the Utilitarians were not able to fend off.

Representative perspective suggested a new approach where the election of incumbents is more important than the direct participation of the citizen in political decisions. Thus, the concepts of common will and human nature were discarded. According to this viewpoint, what conceptualizes democracy is not the primacy of the popular will as a regent of the action of the rulers. On the contrary, popular sovereignty is consolidated by the choice of representatives in the electoral process.

The representative perspective understood that the term democracy finds several types of obstacles in its formulation. In its conception, all conventions are arbitrary and individualized and have oscillated between overly descriptive analysis and exaggerated defense of certain values. The term democracy is no more than a definition that is limited to reproducing in a known language the Greek meaning of the term. Therefore, the ideal does not define and is not defined by the reality. Hence, a real democracy does not mean an ideal democracy put into practice. Although philosophical consensus on a set of fundamental values facilitates the path, it is not a necessary condition for a democracy. In contrast, procedural consensus, that is, agreement on ways of resolving conflicts and complementary norms is the true necessary condition. In other words, procedural consensus is the true prerequisite of democracy (SARTORI, 1994).

In fact, the word democracy is used in amazingly different ways. We use the term both to refer to a goal or ideal and also to a reality that is only a partial achievement of this goal. To face this problem, Dahl (2001) points to a set of criteria and institutions considered as characteristic and necessary for this regime, but stresses that no State has ever had a government that fully complies with all the criteria of a democratic process. In these terms, today's modern democracies are "polyarchies" endowed with a specific set of institutions that establish and share power. In this vein, democracy is an objective to be achieved in a context of political equality where the wishes of different individuals have the same weight, but the desire of the majority prevails. This situation requires some prerequisites. There needs to be general agreement on the method of political competition in a context of social pluralism where economic inequality is fought and restricted. In addition, it is necessary to establish a setting that allows the rise of new leaders. Finally, this view 
Artigo original

Hegemonia - Revista Eletrônica do Programa de Mestrado em Direitos Humanos, Cidadania e Violência/Ciência Política do Centro Universitário Unieuro

ISSN: 1809-1261

UNIEURO, Brasília, número 23, Janeiro a Junho de 2018, pp. 5-26.

of democracy supports a form of government that endorses a number of fundamental rights and guarantees that non-democratic systems cannot provide. For this, it needs a political culture that helps the support of its ideals and practices. The question that remains: is this enough? Since support for democracies has been dropping, it is fair to say that the answer is no. That is why other models gained strength relatively recently.

According to the participatory perspective, democracy is supported by the active citizen that was found firstly in Athens. The followers of this line do not propose a total break with the representative viewpoint. Rather, they suggest the establishment of elections for political offices concurrently with the creation of mechanisms of direct participation that are able to decide on certain issues and influence the behavior of elected representatives when necessary, contradicting the essence of what is defended by the representative current, which is that participation is very important during election time, occupying little space somewhere else in the Schumpeterian theory, since the functioning of the political system would be focused on the action of the leaders. In contrast, Pateman (1992) implies that the seeds of participatory democracy, seen in the classics of antiquity, were mistakenly supplanted by a democratic perspective based on competition among leaders.

In praxis, this view endorsed the strengthened use of mechanisms such as referendums, plebiscites, recalls. These would limit the actions of representatives; offer direct citizen intervention on public policy and enable stronger accountability of the political class. In fact, if we are able to communicate and buy online from almost everywhere in the globe with some security, why not vote on important subjects and decisions? It is obvious why globalized markets and the majority of political elites around the world view this approach as "inadequate".

But what are the drawbacks of each side? If representative perspective can be criticized for its superficiality in terms of political activities, participatory viewpoint can be critiqued for overwhelming the citizen. Analyzing the contrast between representative and participatory perspectives, it is possible to point out that, in fact, when discussing the concept, there is a contrast between the idea of a purely political democracy, characterized by formalism, and that of a substantive democracy, defined by its social character. Przeworski, (1998) stressed that widespread tendency to value a maximalist conception would become a problem due to lack of analytical clarity on the subject. In this view, it would be necessary to use a minimalist meaning. In his final analysis, civil rights are already guaranteed by the rule of law and democracy is presented as a regulated system of choice of representatives, where results may be predictable but not previously known. Thus, the main area of dispute between political interests would be, in fact, the elections. 
Artigo original

Hegemonia - Revista Eletrônica do Programa de Mestrado em Direitos Humanos, Cidadania e Violência/Ciência Política do Centro Universitário Unieuro

ISSN: 1809-1261

UNIEURO, Brasília, número 23, Janeiro a Junho de 2018, pp. 5-26.

On the other hand, the the minimalist vision proposed above has inconsistencies. Certain social conditions generate obstacles to the consolidation of a democracy that guarantees the fullness of the political and civil rights. Contrary to what the minimalist view proposes, the articulation of agreements around public policies, of economic and social content, between different groups of civil society and the State is essential for the construction and maintenance of the institutional stability that characterizes democratic commitment. In this model, the state must act in the pursuit of the public interest with an adequate level of autonomy in relation to particular social interests. On the other hand, the social whole needs the availability of autonomous agents, individual and collective, capable of acting freely and, to the extent that is permissible, equally (REIS, 2000). This would be done by choosing public policies directly.

E-democracy, as an example of the aforementioned, is generally regarded by most as an approach for amplified and improved citizen participation in democratic processes, through the electronic enhancement of political systems. Technology adoption and diffusion promotes cheaper/wider contact and delivery of government services. However, in despite of this admirable new world of possibilities, challenges towards e-democracies have become progressively evident, especially within developed countries. Some researches demonstrate that very few e-democracy proposals endure the period of formal political decision-making and strive to become practical egovernment projects, both nationally and worldwide. Additionally, the enactment of these proposals is undertaken at a considerably slower speed and with much less support than the application of similar e-administration, processes in the public sector. It is also important to stress, once again, that politicians act as veto players focused on inhibiting these changes. ${ }^{3}$

In a purely representative point of view, Democracy is consolidated when there is a minimum procedural consensus with respect to political institutions, namely, secret ballot, universal suffrage, regular elections, party competition, access and recognition of associations and accountability of the Executive. In this context, the democratization of social relations, beyond the political sphere, is not a condition, but a possible consequence of the normal functioning and strengthening of political institutions. Taking into consideration the example of consolidated democracies, the strengthening of a representative logic by the construction of effective institutions and inherent political practices cannot be forcibly implemented. On the contrary, the emergence, strengthening and legitimation of such practices and institutions take time (O’Donnell, 1992).

\footnotetext{
3 Towards the enhancement of e-democracy: identifying the notion of the 'middleman paradox'.
} 
Artigo original

Hegemonia - Revista Eletrônica do Programa de Mestrado em Direitos Humanos, Cidadania e Violência/Ciência Política do Centro Universitário Unieuro

ISSN: 1809-1261

UNIEURO, Brasília, número 23, Janeiro a Junho de 2018, pp. 5-26.

Common sense about the democratic model is that all those affected by a decision should have the opportunity to participate in the process that originated it, either directly or through elected representatives. The second point is that the will of the majority must prevail. This does not mean that, while the victors monopolize government deliberations, those who have been defeated electorally should be satisfied with the withdrawal of power (and government), limiting themselves to distant criticism. On the contrary, excluding loser groups from participation in decision-making processes is a violation of the main assumption of democracy. In this sense, every democracy should pursue some kind of middle ground where representation is maintained but the use of direct mechanisms is amplified. The US has a history of advancements, especially with the use of recalls and referendums, but the use information technology (IT) to spread formal direct choice of public policies has been significantly slow. Anyhow, the situation is worse in most of the other democracies and especially shoddier in developing democracies such as Brazil. But if this kind of advancement is overwhelmingly immense, could we at least reshape and democratize the political parties?

\section{RETHINKING POLITICAL PARTIES IN A GLOBALIZED CONTEXT}

The way we view political parties, as understood today, is quite recent. Although similar organizations of the $18^{\text {th }}$ century are considered embryos of the current political parties, they do not have the same structure. During this period, properly structured government programs and political activities outside parliament were not common. These groups were not linked to the popular will, acting for specific interests within the institutional framework. The concept of a current political party emerged only throughout the nineteenth century from the expansion of suffrage. Silva (2007) points out that legal and institutional recognition occurred only in the 20th century, especially after the Second World War (Sartori, 1976). After all these years, the core definition of political party continues to be problematic construct.

Several scholars have addressed the issue of the definition of a political party presenting convergent and divergent points. in Weber's point of view, these organizations are established voluntarily and aim at a deliberate goal, be it objective or the realization of a plan with material or ideal purposes, whether personal, destined to obtain benefits and power. Possibly, a party can turn to all of these goals together (COSTA, 2000). 
Artigo original

Hegemonia - Revista Eletrônica do Programa de Mestrado em Direitos Humanos, Cidadania e Violência/Ciência Política do Centro Universitário Unieuro

ISSN: 1809-1261

UNIEURO, Brasília, número 23, Janeiro a Junho de 2018, pp. 5-26.

In Michels's (1982) conception, the experience of the left-wing political parties of Western Europe in the early twentieth century reveals that party associations, initially designed to foster the development of political democracy, inevitably become oligarchic. This phenomenon would be an inexorable tendency because the imperative of leadership transforms organizations, raising the need for an experienced professional class capable of centralizing management. As a result, party oligarchy weakens other political institutions and ends up prevailing over democratic principles, putting political and civil societies at risk of disintegration.

From another viewpoint, parties can be seen as voluntary organizations of people for the purpose of gaining power by constitutional means. In this sense, a party is not naturally committed forever with any particular political line, being able to change it in whole or in part and still remain the same party. In other words, a party is very similar to a comet, having a solid nucleus on its head and a long gaseous tail following it (FIELD, 1959).

The political parties analyzed in Marx in the nineteenth century bear very little resemblance to today's party machines. Even so, it is possible to make pertinent considerations using Marxist analysis. This line of thought understands these associations as part of a broader historical process of social transformation called the political movement. According to this review, in all capitalist countries there are parties that are favored as vehicles or instruments of the ruling classes, constituted by business and property holders (MILIBAND, 1985).

Despite the multiplicity of meanings that are found, we can deduce a common tendency for defining parties. This composition is established as follows: a social group; a principle of organization; a wealth of ideas and principles that inspire the party's action; a basic interest in sight: the seizure of power; and finally, as a sense of conservation of this power or domination of the government apparatus when it comes to hands (BONAVIDES, 1974).

Taking into consideration what has been aforementioned, it is possible to establish a number of important points. The only convergence (in all authors) with regard to party characteristics is: commitment to the acquisition, division, and maintenance of power. No emphasis was is placed on long-term commitment to principles or ideologies to be championed. Not even effective commitments as to the implementation of democratic policies within the party group. On the basis of the definitions, it is possible to conclude, therefore, that political parties do not necessarily have to be democratic institutions, although they are essential to representative democracy. This gives rise to a peculiar paradox where the fragility of party systems in modern societies remains unanswered (Mahrer \& Krimmer, 2005). In addition to providing too much freedom for party institutions and individuals, the above definitions do not address issues of party 
Artigo original

Hegemonia - Revista Eletrônica do Programa de Mestrado em Direitos Humanos, Cidadania e Violência/Ciência Política do Centro Universitário Unieuro

ISSN: 1809-1261

UNIEURO, Brasília, número 23, Janeiro a Junho de 2018, pp. 5-26.

duties and responsibilities, nor do they address obligations that could be presented as simpler forms of accountability. In fact, several authors have looked into the subject and pointed out the need to revise the concept, rights, duties and functions of political parties and other institutions as a way to broaden and strengthen democracy (BENEVIDES, 2003; ABRUCIO, 2003, among others).

In response to this problem, it is necessary to delineate a new vision on political parties, more appropriate the new reality. For decades parties were seen as voluntary associations whose purpose was to promote an ideological agenda, engagement in social mobilization and educational efforts. This approach is no longer dominant. Nowadays, it is necessary that the parties be understood, above all, by their relations with the State. In other words, they are semipublic institutions that play an important role in democracy. Therefore, they must be transparent and financially healthy so that they can respond to democratic demands of society (HOFNUNG, 2008).

On the basis of this last view - and others similar - parties must first be conceived as semipublic institutions whose ties with the State are stronger than the ties with society, due to the logic of electoral competition and (where it happens) the use of public funding. Secondly, it must be understood that, in the vast majority of cases, parties also no longer espouse ideologies. Rather, they represent distinct management models that are subject to voter assessment and scrutiny. Even in the rare cases where specific ideologies and values are to be flags, one must accept that they are relatively fluid and can be modified over the years, especially in the event of a transition from government to opposition and vice versa.

Thirdly, it is necessary to insert democratic values into party systems. Not only because they are pillars of democracy, but because of the fact that they are systematically increasing the use of public revenues as the main means of support. This implies combating oligarchies through rules that promote internal (pre-electoral) competition so that the struggle for public office is progressively more inclusive and transparent. This set of factors has a clear reflection on the way citizens should discuss electoral alliances, party loyalty, as well as the need for a review on the ways of controlling revenues and expenses.

\section{RECONSIDERING ELECTORAL SYSTEMS}

The internal logic of the parties and the party system as a whole affects the electoral system. It is also possible to say that oligarchic party systems have negative consequences for democracy, which weakens the political system by generating a vicious cycle (SARTORI, 1996). The reason for the process of party oligarchization has two cores. The first refers to the need that 
Artigo original

Hegemonia - Revista Eletrônica do Programa de Mestrado em Direitos Humanos, Cidadania e Violência/Ciência Política do Centro Universitário Unieuro

ISSN: 1809-1261

UNIEURO, Brasília, número 23, Janeiro a Junho de 2018, pp. 5-26.

states have for stable political organizations. The second nucleus points out that the masses are not prepared for the effective practice of democracy and, consequently, are predisposed to give up control in favor of an oligarchy (MICHELS, 1982). In other words, all minimally organized and efficient equipment, for tactical and technical reasons, needs supervisors. This need creates a form of organization that is, at the same time, the foundation of modern democratic process and the source of elitist domination. In short, organization means oligarchy. This permanent antagonism between inert oligarchy and the democratic participation within parties is one of the central points of the political debate about the necessity and effectiveness of the party systems.

Besides the paradigm of oligarchy, mentioned above, one has the question of the dimension of interparty relations. The relationships between electoral alliances and government alliances are very complex, and the second does not necessarily require the former, and vice versa. Therefore, it is easier to unite in the pursuit of positions in parliament by means of momentary agreements, than a stable alliance by the division of power (DUVERGER, 1962). The latter demands the acceptance of a common program and more affinity between the parties. Thus, there is another contradictory character regarding the elective process, especially in proportional systems. Once this process is consolidated, established government alliances are significantly different than those founded before elections because rarely does a party achieve an absolute majority in parliament. In other words, parties act independently from each other in the first moment and are forced to collaborate in the second. This usually makes it difficult to form stable and lasting parliamentary coalitions. Moreover, it makes government majorities more unstable.

This paper sought to present some of the problems concerning the quest for a concrete democracy project, rethinking the role of parties and identifying aspects of those systems that need reform. Moreover, it pointed to other problems associated with the electoral system and the distance of voters, due to the disconnection between parties and voters, among others, as well as the inability of the parties to deal with current social, economic and political problems.

The analysis of the literature has shown that, in the face of these questions, other problems associated with electoral systems (number of parties, open or closed list, and district vote) are much less important. There is no perfect recipe. Several experiences analyzed in the literature expose how the elaboration of rules for political financing in the broad sense is extremely complex. Its efficiency is relative and the cost can be very high, especially with regard to public subsidies. They also point out that corruption scandals are a reality of politics, regardless of the culture of the people or the degree of institutionalization. Sooner or later, the political actors will find alternative ways to overcome the barriers to private financing and try again to influence politics. Therefore, it 
Artigo original

Hegemonia - Revista Eletrônica do Programa de Mestrado em Direitos Humanos, Cidadania e Violência/Ciência Política do Centro Universitário Unieuro

ISSN: 1809-1261

UNIEURO, Brasília, número 23, Janeiro a Junho de 2018, pp. 5-26.

is necessary to accept that rules of electoral systems are not definitive and that the political apparatus will have to go through constant scrutiny and alteration to keep up with changes in political behavior and ideal democratic protection.

In general, public funding experiences seen abroad have shown that this is the best solution to ensure that party systems can keep up with the increase of election costs and still pay off their debts. They also provide more support for small parties. This has been such a strong trend that exclusively private financing proposals are not even an option anymore. An example of this is the case in England, where private financing has been widely questioned. Part of this is due to the importance given to private subsidies from individuals. The evaluation of a significant part of the literature on partially state-funded backing has shown that increasing the distance between parties and voters, motivated (among others) by large-scale public funding, is a reality. In this case, increasing the proportion of state subsidies and combining it with restrictions on the permitted expenditure (Belgium, Spain and Portugal) with the reduction of the electoral period (15 days in Spain) and with the accountability of all actors may be more efficient. On the other hand, exclusively public financing without sufficient structure for its inspection seems to be a fiction exercise that, unfortunately, is always again discussed in the Brazilian case.

If parties are able to recycle, strengthen and gain more weight in the global political game, they will have to accept that they will be held accountable for any similar crises and corruption scandals. This does not happen nowadays because, in general, much of the responsibility is still personalized and the negative impact of disillusionment with government and institutions is subdivided (to a greater or lesser extent) among all politicians. This is clearly the case in Brazil and, to a lesser extent, in all democracies. In the American case, Donald Trump is the classic example of personalism. Adopting an open or closed list model can direct accountability to parties or politicians. However, they are changes of marginal impact and the political class will, in practice, adapt to them in the medium term, as it does with the illicit or inadequate acts of large corporations whose brands are affected, but without necessarily punishing their shareholders, interlocutors and owners.

Nonetheless, the path taken by democracies to obtain simpler, more secure and fair electoral rules is also subject to voter influence, something that demonstrates both the strong desire for a more personalized type of accoutability when the socioeconomic situation is really bad. Despite keeping the list closed system, Portugal and Spain did not fail to go through similar situations where these instruments were severely questioned. The quest for more flexibility and 
Artigo original

Hegemonia - Revista Eletrônica do Programa de Mestrado em Direitos Humanos, Cidadania e Violência/Ciência Política do Centro Universitário Unieuro

ISSN: 1809-1261

UNIEURO, Brasília, número 23, Janeiro a Junho de 2018, pp. 5-26.

personal accountability also demonstrates a severe criticism of internal candidate choice processes in democracies. In this respect, Brazil does not escape the rule of having internally undemocratic parties whose selective processes are unruly and nebulous.

Therefore, using parties as a shield or receptor for different types of criticism without effectively addressing the problems faced by society and without sharing responsibility for choices with voters implies, sooner or later, the weakening of democracy by diminishing political and electoral participation. As political systems represent possibilities, but not guarantees, to place excessive reliance on the merits of spectacular reforms without realizing how their disadvantages help to weaken the political systems of other democracies can represent a serious setback for Brazil. After a few years of its completion, we may be again discussing the need to take a step or two back. It is in this context that the adoption of similar models to those used in other democracies can mean a productive medium where, although not all the desired objectives are achieved (institutional accountability, targeted political financing, more proportional female participation, etc.), some disadvantages such as the rise of party oligarchies and distancing of politicians from voters can be avoided.

Electoral and party systems are not products whose satisfaction is guaranteed. Specific models have different purposes and the socioeconomic and cultural profile of their consumers is an extremely important variable for their success. The results also do not appear in the short term and the amount of unexpected effects increases according to the intensity of the changes implemented.

Regardless of the choices in terms of electoral law, attention must also be focused on the rules that govern their creation, a problem that affects the almost absolute majority of contemporary democracies. The search for more electoral regulation contrasts with disregard for pre-electoral regulation, a field in which the parties have an excessive degree of freedom, which negatively influences the entire political process and the bases of democracy. In Brazil this is patent. In this case, the resolution is conditioned to changes in the financing rules of the pre-electoral selection process. However, despite the profound changes in the way the laws concerning the allocation of public campaign resources among the different bodies and positions in dispute, the proposals analyzed do not alter the (dis) regulation of the intraparty dispute.

Although changes in the electoral system are necessary, there are no guarantees, only expectations that they will achieve the goals. In the Brazilian case, these goals would be strong, cohesive, disciplined, better supervised and independent parties. But stronger support for 
Artigo original

Hegemonia - Revista Eletrônica do Programa de Mestrado em Direitos Humanos, Cidadania e Violência/Ciência Política do Centro Universitário Unieuro

ISSN: 1809-1261

UNIEURO, Brasília, número 23, Janeiro a Junho de 2018, pp. 5-26.

democracy depends on other conditions that are far beyond political regulation, such as the strengthening of Electoral Justice, for example. In addition, it is uncertain whether the costs associated with any changes (party oligarchy, end of personal vote and individual accountability, exponential increase in public campaign costs, etc.) are clearly reasonable.

Before starting reform processes, we must take into account that the objectives of many electoral reform proposals are not fully achievable because the combination of politicians' creativity, gaps in the law and lack of supervision would quickly find alternative routes for illicit practices and funding. Therefore, to a lesser extent, the distortions would remain. The strengthening of the parties due to the exchange of personalist and fratricidal competition by effectively leading campaigns would be counterbalanced by the setback of the unregulated clash between the various groups in the selection process for the definition of the places on the list.

It is at this point that oligarchic institutions can persist or gain even worse contours. It is possible that the list-making body becomes the new battleground that involves the process of oligarchic molding. The battle to control the best positions on the lists would involve a lot of money and give a new dimension to the confrontation between the old party leaders and the new political actors. Moreover, the dependence that candidates have on their financiers and other interest groups today will remain, since these actors will participate intensively in the intra-party selection process. This set of factors, combined with widespread disregard and disillusionment with politics, would promote an even greater distance from the parties in relation to the ordinary citizen, and vice versa. Consequently, perhaps opting for changes that compel parties to develop more democratic and transparent instruments for selecting their candidates, coupled with minor changes to the model, bring more solid and secure positive results than broader changes.

In this context, it may be wiser to discard exclusive public funding, thus allowing the flexible list to be adopted, a procedure that maintains many of the qualities of the open system, but at the same time gives the parties more control over the lists without withdrawing of the voter's power of intervention and punishment. In addition, nothing prevents the centralization of campaign resources in parties or the adoption of quota policies are inserted in this model, provided that making use of some adaptations. Continuing the commitment to adopt the closed list without attention to these issues can turn out to be an unsuccessful effort to strengthen the party system and democracy. 
Artigo original

Hegemonia - Revista Eletrônica do Programa de Mestrado em Direitos Humanos, Cidadania e Violência/Ciência Política do Centro Universitário Unieuro

ISSN: 1809-1261

UNIEURO, Brasília, número 23, Janeiro a Junho de 2018, pp. 5-26.

\section{PARTIES: AUTOCRATIC INSTITUTIONS INSIDE DEMOCRATIC SYSTEMS}

There are divergent views on the characteristics and proper role of political parties inside democratic systems. For some, is clear their importance to representative structures, without which democracy would not be viable (ZOVATTO, 2005). For others, political parties can serve multiple functions. They are needed to build and aggregate support across broad coalitions of organizations and interest groups; to transform multiple conflicting demands into coherent programmatic policies; to select and train political leaders; to provide voters with choices among government and policy teams and; if elected, to organize the governance process and be collectively held accountable for their actions in subsequent elections (NORRIS, 2005). Consequently, in terms of the representative model, democracy is not possible without party competition, since political parties function accordingly and constitute one of the pillars of this kind of arrangement. The long list of potential functions can be summarized in five main aspects: integration and mobilization of citizens; articulation and aggregation of interests; formulation of public policies; recruitment of political leaders; legislative and government organization.

On the other hand, to some of the contemporary authors, mainly advocates of participatory, direct or deliberative democracies, parties are viewed with suspicion, under the premise that citizens should discuss the issues and set priorities within each community, without the influence of party interests. This perspective, although modified, has its roots in Madison ${ }^{4}$ and Rousseau (1986), authors who saw the parties as foreign interests to those represented, prone to weaken, pervert or usurp the will of the majority. In this perspective, parties would be artificial organizations, uncompromising and constituted by candidates who construct vague personal images (MANIN, 1995). Moreover, factions would be motivated by passions or particular interests, antagonistic to the interests of citizens and the permanent interests of the community.

The issue of distrust in politics has also been studied in various parts of the world since the middle of the last century. Comparative analyzes revealed, in countries such as Italy and Germany, a degree of endemic mistrust, widespread and rooted in the social context (MOISÉS, 2005). In England, France, and Sweden, confidence levels in institutions have fallen steadily over the last thirty years. Analysis of research conducted over the past 30 years has shown that

\footnotetext{
${ }^{4}$ See Hamilton et. al, 1984.
} 
Artigo original

Hegemonia - Revista Eletrônica do Programa de Mestrado em Direitos Humanos, Cidadania e Violência/Ciência Política do Centro Universitário Unieuro

ISSN: 1809-1261

UNIEURO, Brasília, número 23, Janeiro a Junho de 2018, pp. 5-26.

confidence levels in institutions and governments in these countries have declined from over 75\% to about $25 \%$. Several countries that composed the third wave of democratization also presented problems associated with mistrust (Huntington, 1991). The crisis of 2008 has helped to strengthen this trend in countries such as Spain, Portugal, Greece, France and in the latest election results for parliament in 2013 in Italy. Concomitantly, they also enabled the strengthening of anti-system parties in England, France and Germany. This state of affairs has been worrying people, around the world, who are involved with agendas that engage inequality, strengthen democracy and promote human rights.

Latin American nations also presented worrying statistics about trust in political parties. Studies on electoral results in this region indicated that voters seem more suspicious and more disenchanted with politics. The consequence seems to have been the institutionalization of a generalized apathy towards the conventional means of politics (formal parties, elections and formal procedures in general (BAQUERO, 2003). According to Latinobarómetro 2004, a public opinion survey that covered eighteen Latin American countries, political parties are the institutions that generate the least confidence in the population (RUBIO, 2005). In another Latin American survey, two-thirds of respondents demonstrated varying degrees of distrust in the legislature, political parties and courts of justice, among others (LAGOS, 1997). In the same vein, studies pointed to the limited credibility of the Brazilian parties, which reached the level of 49\% distrust (Dulci, 2003). More recently, Baquero \& Gonzáles (2012) pointed out that democracy finds broad support in Brazil. However, political support for public values, institutions and managers has declined. Citizens are more critical of political leaders and government institutions. In addition, they identify themselves less and less with political parties and believe that the government works in order to benefit a minority. In other words, support for democracy is contrasted by dissatisfaction with how democratic institutions function in Brazil. This changed after the 2015/16 economic and political crisis. Since then, the backing of democracy has been diminishing and support for extreme, autocratic and antisystem agendas and candidates such as Jair Bolsonaro, an retired military and member of Congress, has been growing significantly.

On the other hand, there is another view that rejects that the erosion of confidence in politics could be associated with a more encompassing phenomenon of political alienation. On the contrary, there has been no decline in political participation in Western democracies in the last thirty years. What is, in fact, occurring is a crisis of traditional forms of conventional participation that are driven by economic and political elites (CASTILLO, 2003). Another way of glimpsing the 
Artigo original

Hegemonia - Revista Eletrônica do Programa de Mestrado em Direitos Humanos, Cidadania e Violência/Ciência Política do Centro Universitário Unieuro

ISSN: 1809-1261

UNIEURO, Brasília, número 23, Janeiro a Junho de 2018, pp. 5-26.

issue is that Western citizens have opted for unconventional forms of participation, demonstrating the importance of the crisis of confidence in public institutions.

\section{WHAT DO WE DO NEXT?}

Political institutions in many countries but, especially in undeveloped ones, face a number of difficulties. In fact, the dichotomy between the various global and national interests has been unbalanced in favor of the former. The crisis generated by the deregulation of capital markets and the downsizing of the state (privatizations, creation of regulatory agencies, etc.) are examples of how decisions about domestic politics have been heavily influenced by externally produced interests and values, the precepts of representative democracy, to the extent that the will of voters significantly influences less decision-making on government policies. Concurrently, successive governments have had great difficulty in dealing with problems associated with the general lack of government output. This has been eroding the image of political institutions with civil society. Other views, by focusing its concerns on Legislative behavior and its interaction with the Executive Power, do not give due importance to the need to seek voting equality. Concomitantly, most attempts to transform the system in order to make it more democratic and intelligible to the voter have been ineffective and frustrating.

Arguments that challenge positive evaluations of political systems globally are consistent, demonstrating that the defense of current models is based on biased positions on the meaning of cohesion and cooperation. Furthermore, they demonstrate that this position does not adequately respond to the need for sharper party profiles with the electorate; disregards the negative effects of oligarchy control of these institutions and tolerates the excessively heterogeneous nature of electoral system flaws. At the same time, look the other way to the problems associated with fragile post-electoral alliances in many countries.

One way of solving, at least in part, the aforementioned problems is to gather in a single package a set of measures to achieve certain objectives that are in principle commendable: the consolidation of the political system based on the strengthening of the parties, the restriction to the influence of the private capital and in combating the fragmentation of power. This is undoubtedly an advance on the chaos that has been political representation around the globe, since most of the parties present government proposals that are based on a mix of illusory assumptions 
Artigo original

Hegemonia - Revista Eletrônica do Programa de Mestrado em Direitos Humanos, Cidadania e Violência/Ciência Política do Centro Universitário Unieuro

ISSN: 1809-1261

UNIEURO, Brasília, número 23, Janeiro a Junho de 2018, pp. 5-26.

and the result of calculating personal advantages. One must accept, however, the fact that fighting these adversities does not depend only on procedural changes. They certainly help in the quest for consistent and democratizing institutional advances. But alone, they will not live up to the expectations that have been created. A certain amount of skepticism (not to say cynicism) is necessary to realize the limits of any changes in terms of electoral and party reform In this sense, slow and studied movements should be very welcome.

In this vein, there are two constraints that need to be verified. First, if liability is acceptable, it is very important to remember that the need for change does not imply that any change is welcome. Second, proposed changes actually reach the proposed results? What are those results? Since certain modifications can easily aggravate the situation or incur unexpected problems whose results can be catastrophic for the political system, maintaining certain characteristics of the system may not be such a bad choice. Other changes, while beneficial, can generate non-estimated costs that simply make them unfeasible. In other cases, there may be efficient alternatives that are simpler and less costly. Finally, weights and checks must be established. In other words, we need to turn parties into stronger and more independent institutions, but at the same time, enforce the need for them to be more democratic and transparent. This second part cam be done by promoting instruments of direct democracy such as recalls, referendums, plebiscites and popularization of technology of information in political participation. At the same time, reduce the political cost of governance by restraining certain veto-players (smaller parties, big businesses and bureaucracy, etc.) and by strengthening party leaders. It is also not possible to forget the right of the voter to understand and concretely intervene in an intelligible selection process.

\section{CONCLUDING REMARKS}

The concise elucidation of the understanding of few authors about the many concepts of democracy, parties and aspects of electoral reforms demonstrates both the complexity of these themes and their importance for the construction of models of participation, representation and decision making. The exposition of the concepts and its obstacles also pursued the objective of demonstrating the complexity of the theoretical discussion.

With regard to the consolidation of democracy, a balance must be struck between the various perspectives, especially the representative and participatory. On the one hand, institutional changes need to go beyond the excessively limited concern with procedures for selecting 
Artigo original

Hegemonia - Revista Eletrônica do Programa de Mestrado em Direitos Humanos, Cidadania e Violência/Ciência Política do Centro Universitário Unieuro

ISSN: 1809-1261

UNIEURO, Brasília, número 23, Janeiro a Junho de 2018, pp. 5-26.

representatives and leaders. They need to create mechanisms that encourage political participation and that can establish popular confidence in democracy at high levels. On the other hand, it is necessary to keep a distance from concepts and values that are too subjective. In addition, it is necessary to understand that the expected objectives of democratic consolidation also depend on other socioeconomic and cultural conditions. In other words, it is salutary a certain amount of skepticism in relation to the positive results that institutional reforms can leverage, especially in countries that are subject to the ills of "delegative" democracy, that is, marked by political passivity and individualism, legalism and corrosion institutions.

In this vein, the various classical definitions of political parties do not give consensual emphasis to any kind of long-term commitment to proposals, principles or ideologies. They contradict other perceptions of the parties as engaged in promoting an ideological agenda and social mobilization. Neither of these two perspectives fits adequately into today's reality, where parties are semi-public institutions that represent far more distinct models of management than ideologies. In addition, they are generally highly dependent on state funding and closely linked to government bureaucracy. Therefore, a truly democratic political reform proposal would need to enforce the need for more transparent, more inclusive and less oligarchical parties. This cannot be done without embracing the newest information technology advancements. Only then, will we be able to mitigate the disillusionment with politics and help consolidate true democratic ideals.

\section{REFERENCES}

ABRÚCIO, F. L. Reforma política e Federalismo: desafios para a democratização brasileira. In: BENEVIDES, M.; KERCHE, F.; VANNUCHI, P. (Org.). Reforma política e cidadania. São Paulo: Fundação Perseu Abramo, 1a ed. 2003. p. 225-265.

BAQUERO, M. Construindo uma outra sociedade: o capital social na estruturação de uma cultura política participativa no Brasil. Curitiba: Revista de Sociologia Política, n. 21, p. 83-108, 2003. Disponível em: $\quad<$ http://www.scielo.br/scielo.php?script=sci_arttext\&pid =S010444782003000200007\&lng=en\&nrm=iso $>$.

BAQUERO, M. GONZÁLEZ, R. Obstáculos à construção de uma "nova” sociedade na América Latina. Qual é a utilidade do conceito de capital social nesse processo?. Revista Brasileira de Ciência Política, n. 3, p. 253-287, 2012.

BENEVIDES, M. Nós, O povo: reformas políticas para radicalizar a democracia. In: BENEVIDES, M.; KERCHE, F.; VANNUCHI, P. (Org.). Reforma política e cidadania. São 
Artigo original

Hegemonia - Revista Eletrônica do Programa de Mestrado em Direitos Humanos, Cidadania e Violência/Ciência Política do Centro Universitário Unieuro

ISSN: 1809-1261

UNIEURO, Brasília, número 23, Janeiro a Junho de 2018, pp. 5-26.

Paulo: Fundação Perseu Abramo, 1a ed. 2003. pp. 83-119.

BONAVIDES, P. Ciência política. Rio de Janeiro: Fundação Getúlio Vargas, Serviço de Publicações. 2a ed. 1974.

BONIFACIO, Robert. José Álvaro Moisés (org) - Democracia e confiança: por que os cidadãos desconfiam das instituições públicas?. Rev. Bras. Ciênc. Polít. [online]. 2012, n.7, pp. 399-406. ISSN 0103-3352.

CASTILLO, A. Political culture and representative democratic institutions in Spain. In: 6th ESA CONFERENCE, Political Sociology, Streams 9, 2003, Murcia. Proceedings published online. Disponível em: http://www.um.es/ESA/papers/St9_63.pdf.

COMPARATO, F. A garantia Constitucional contra o abuso de poder. In: BENEVIDES, M.; KERCHE, F.; VANNUCHI, P. (Org.). Reforma política e cidadania. São Paulo: Fundação Perseu Abramo, 1 a ed. 2003. p. 44-56.

COSTA, P. R. N. Dossiê Democracia, políticos e partidos. Revista de Sociologia e Política, Curitiba, n. 15, p. 7-9, novembro 2000. Disponível em: http://www.scielo.br/pdf/rsocp/n15/a01n15.pdf.

DAHL, R. Poliarquia: participação e oposição. São Paulo: Edusp, 1997. 234 p. Sobre a Democracia. Brasília: Editora Universidade de Brasília, 2001.

DAHL, R. \& LINDBLOM, C. Política, economia e bem estar social. São Paulo: Lidador, 1971. 519 p.

DALTON, R. \& WELDON, S. Public images of political parties: a necessary evil? West European Politics, vol. 28, p. 931-51, 2005.

DULCI, O. S. A incômoda questão dos partidos no Brasil: notas para o debate da reforma política. In: BENEVIDES, M.; KERCHE, F.; VANNUCHI, P. (Org.). Reforma política e cidadania. São Paulo: Fundação Perseu Abramo, 1a ed. 2003. p.300-320.

DUVERGER, M. Ciência Política Teoria e Método. Rio de Janeiro: Zahar Editores, 1a ed, 1962. FIELD, C. G. Teoria Política. Rio de janeiro: Zahar Editores, 1a ed.,1959.

HAMILTON, A.; MADISON, J \& JAY, J. (1984) O Federalista. Brasília: Editora Universidade de Brasília.

HOBBES, T. (1682) Leviathan, or, The matter, forme, \& power of a common-wealth ecclesiasticall and civill. London. Penguin.

HOFNUNG, M. (2008) Unaccounted Competition: The Finance of Intra-Party Elections. Party Politics, Sage Publications, vol 14. n.6 p. 726-744.

HUNTINGTON, S. The Third Wave. Democratization in the Late Twentieth Century. Oklahoma 
Artigo original

Hegemonia - Revista Eletrônica do Programa de Mestrado em Direitos Humanos, Cidadania e Violência/Ciência Política do Centro Universitário Unieuro

ISSN: 1809-1261

UNIEURO, Brasília, número 23, Janeiro a Junho de 2018, pp. 5-26.

City: University of Oklahoma Press, 1991.

LAGOS, M. Latin America's smiling mask. Journal of Democracy, Washington: The Johns Hopkins University Press, n. 8. 1997.

LIJPHART, A. Democracies: forms, performance, and Constitutional engineering. European Journal of Political Research, 25, 1-17. January, 1994.

Patterns of Democracy: government forms and performance in thirty-six countries. New Haven: Yale University Press, 1999.

. Modelos de Democracias. Rio de Janeiro: Civilização Brasileira, 2003.

MAINWARING, S. Sistemas partidários em novas democracias: o caso do Brasil. Porto Alegre/Rio de Janeiro: Mercado Aberto/FGV, 2001.

MANGAHAS, M. Social Climate: satisfaction with the way democracy works. Inquirer, Manila, 11 de novembro, 2007. Disponível em: http://opinion.inquirer.net/inquireropinion/ columns/ view_article.php?article_id=102832.

MANIN, B. As metamorfoses do governo representativo. Revista Brasileira de Ciências Sociais, n. 29, Ano 10, outubro de 1995. Disponível em: http://www.anpocs.org.br/portal/publicacoes/rbcs_00_29/rbcs29_01.htm

MICHELS, R. Sociologia dos partidos políticos. Brasília: Editora. UnB, 1982. Coleção Pensadores Políticos, n. 53.

MILIBAND, R. The state in capitalist society: an analysis of western system of power. New York: Ed. Basic Books, Inc., Publishers, 1985.

MOISES, J. A desconfiança nas instituições democráticas. Opin. Publica, Campinas, v. 11, n. 1. p.33-63. 2005. DOI: 10.1590/S0104-62762005000100002. Disponível em: <http://www.scielo.br/scielo.php?script=sci_arttext\&pid=S0104-62762005000100002\& $\operatorname{lng}=\mathrm{en} \& \mathrm{nrm}=\mathrm{iso}>$.

NORRIS, P. Choosing electoral Systems: proportional, majoritarian and mixed systems. International Political Science Review, v. 18 (3), p. 297-312, julho de 1997. Edição especial: “Contrasting Political Institutions". Disponível em: www.pippanorris.com.

Building political parties: reforming legal regulations and internal rules. Report for International IDEA Strengthening Parties, 2005. Disponível em: http://www.idea.int/parties/upload/pippa\%20norris\%20ready\%20for\%20wev\%20_3_.pdf.

NUSSBAUM, M. Not for profit: why democracy needs the humanities. Princeton: Princeton University, 2010.

O`DONNELL, G. Democracia Delegativa?. Novos Estudos CEBRAP, São Paulo, n. 31, p. 25- 
Artigo original

Hegemonia - Revista Eletrônica do Programa de Mestrado em Direitos Humanos, Cidadania e Violência/Ciência Política do Centro Universitário Unieuro

ISSN: 1809-1261

UNIEURO, Brasília, número 23, Janeiro a Junho de 2018, pp. 5-26.

40, 1991.

PAIVA, D.; SOUZA, M.R.; LOPES, G. de F. As percepções sobre democracia, cidadania e direitos. Opin. Publica, Campinas, v. 10, n. 2, p. 368-376. Oct. 2004 . Disponível em: <http://www.scielo.br/scielo.php?script=sci_arttext\&pid=S0104-62762004000200008\&lng

$=$ en $\&$ nrm $=$ iso $>$.

PATEMAN, C. Participação e Teoria Democrátia. Rio de Janeiro: Paz e Terra, 1992. 187

PRZEWORSKI, A. Deliberation and ideológical domination. In: Elster, J. (Ed.). Deliberatve Democracy. Cambridge: Cambridge University Press, 1998. p. 140-160.

REIS, F. Atualidade mundial e desafios brasileiros. Estudos Avançados, São Paulo, v. 14, n. 39, 2000. DOI: 10.1590/S0103-40142000000200003. Disponível em: <http:// www.scielo.br/scielo.php?script=sci_arttext\&pid=S0103-40142000000200003\&lng= en\&nrm $=$ iso $>$.

ROUSSEAU, J. Political Writings. Madison: University of Wisconsin Press, 1986.

RUBIO, D. F. Financiamento de partidos e campanhas: fundos públicos versus fundos privados.

Novos Estudos - CEBRAP, São Paulo, n. 73, 2005. Disponível em: <http://www.scielo.br/scielo.php?script=sci_arttext\&pid=S0101-33002005000300001\&lng $=\& n r m=$ iso $>$.

SARTORI, G. Parties and party systems: a framework for analysis. Cambridge, Cambridge University Press, 1976.

A Teoria da Democracia Revisitada. São Paulo: Ed. Ática, 1994.

Engenharia Constitucional. Brasília: Ed. Universidade de Brasília, 1996.

SCHUMPETER, J. A. Capitalismo, Socialismo e Democracia. Rio de Janeiro: Ed. Fundo de Cultura, 1961.

SILVA, V. Partidos e reforma política. Revista Eletrônica sobre a Reforma do Estado (RERE), Salvador, Instituto Brasileiro de Direito Público, n. 10, p.01-11. Junho/agosto 2007. Disponível em: http://www.direitodoestado.com/revista/RERE-10-JUNHO-2007-

VIRGILIO\%20AFONSO.pdf.

TRINDADE, H. Reforma Política: os desafios da democracia social. In: BENEVIDES, M.; KERCHE, F.; VANNUCHI, P. (Org.). Reforma política e cidadania. São Paulo: Fundação Perseu Abramo, 1a ed. 2003. p. 57-82.

ZOVATTO, D. Financiamento dos partidos e campanhas eleitorais na América Latina: uma análise comparada. OPINIÃO PÚBLICA, Campinas, Vol. XI, no 2, p. 287-336, Outubro, 2005. 